Annals of Warsaw University of Life Sciences - SGGW

Land Reclamation No 48 (2), 2016: 111-122

(Ann. Warsaw Univ. Life Sci. - SGGW, Land Reclam. 48 (2), 2016)

\title{
Hauled liquid waste as a pollutant of soils and waters in Poland
}

\author{
AGNIESZKA KARCZMARCZYK \\ Department of Environmental Improvement, Warsaw University of Life Sciences - SGGW
}

\begin{abstract}
Hauled liquid waste as a pollutant of soils and waters in Poland. Improperly maintained holding tanks are often underestimated source of contamination of soil, groundwater and surface water. As a rule, wastewater stored in holding tanks, should be transported and treated in municipal wastewater treatment plants (WWTPs). There are 2,257,000 holding tanks in Poland, located mainly in rural areas. The article presents the results of analysis of wastewater management in 20 rural and urban-rural communes, which were chosen at random from the total number of 2,174 communes in Poland. The only criterion of commune selection was total or partial lack of sewerage system. Analysis of the collected data showed that on average only $27 \%$ of liquid waste from holding tanks ended at the WWTPs. The median is even lower and amounts to $17.5 \%$. More than $4,000 \mathrm{Mg}$ of $\mathrm{P}$ and $26,000 \mathrm{Mg}$ of $\mathrm{N}$ is dispersed in the environment in uncontrolled manner. Those diffuse point sources of pollution may be one of the reasons in the difficulty of achieving of good ecological status of rivers and affect the quality of the Baltic Sea.
\end{abstract}

Key words: on-site wastewater management, holding tank, uncontrolled discharges, nitrogen, phosphorus

\section{INTRODUCTION}

Protection of water resources against pollution covers the reduction of emissions from point sources, using accepted emission limits, and reduction of emissions from non-point sources (mostly rural areas) through the application of best available techniques (Water Law Act 2001). Point sources are usually well identified, and a lot has been done last years to limit pollutants load from wastewater treatment plants (WWTPs). In Poland, implementation of the National Programme of Municipal Wastewater Treatment (2003) for agglomerations of above 2,000 PE, resulted in significant increase of population connected to municipal WWTPs. Between 2003 and 2012 more than 300 new municipal WWTPs have been constructed and more than 900 modernized. Wastewater treatment plants serving more than 10,000 PE must provide enhanced removal of nutrients. Ecological effect of the mentioned programme is reduction of $82.3 \%$ of $\mathrm{BOD}_{5}, 70.7 \%$ of total nitrogen and $78.6 \%$ of total phosphorus reached in 2013 (Sumisławski 2013). Non-point sources, often understood as agricultural runoff, are responsible for significant inputs of pollutants, mostly nutrients, to surface waters (Verheyen et al. 2015). Suburban and rural areas however, generates pollutants not only at the arable land but also at the connected infrastructure, as well as in residential areas not connected with agricultural production, e.g. small settlements, summer houses, recreation areas etc. Reducing only diffuse inputs from agriculture without considering the contributions of dispersed point sources, e.g. septic tanks or holding tanks may therefore undermine eutrophication control strategies in rural watersheds (Withers et al. 2014, Wood et al. 2015). 
The possible variants of management of domestic wastewater from single houses are: connection of the property to the existing sewerage network or, in case where the sewage system is technically or economically unjustified, using the wastewater holding tank or installation of on-site wastewater treatment plant (Act on maintaining... 1996). Sewer system ended with municipal wastewater treatment plant is the most popular method of wastewater management in urban areas in Poland (93.3\% of total population in cities), but only $35.3 \%$ population of villages is connected to municipal WWTPs (Environment 2014). In rural areas, on-site wastewater treatment is getting more and more popular. Increased interest in this area is expressed by the number of on-site treatment plants constructed in recent years. In year 2000 only 578 on-site wastewater treatment plants with a total capacity of $502 \mathrm{~m}^{3} \cdot \mathrm{day}^{-1}$ have been installed, but in 20051,782 (capacity of $2,101 \mathrm{~m}^{3} \cdot \mathrm{day}^{-1}$ ), in 2010 $10,159\left(19,250 \mathrm{~m}^{3} \cdot \mathrm{day}^{-1}\right)$, in 2012 $11,791\left(22,657 \mathrm{~m}^{3} \cdot \mathrm{day}^{-1}\right)$ and in 2013 15,871 plants with a total capacity of $25,012 \mathrm{~m}^{3} \cdot$ day $^{-1}$ (Environment 2014). However, still septic tank with the drainfield is the most popular solution for on-site wastewater management in Poland and many other countries (Eveborn et al. 2014). In Europe 26\% of households rely on this system (Williams et al. 2012). Simple septic systems have many disadvantages and can create environmental risks. According to Withers et al. (2014), it can be a major, and potentially underestimated, source of water pollution. The environmental risk increases significantly if density of such systems is high (Szustakowski and Halicki 2004, Arnscheidt et al. 2007). More advanced on-site wastewater treatment plants are also implemented, but without proper maintenance they often fail, and the quality of effluent is comparable to simple septic system (Karczmarczyk

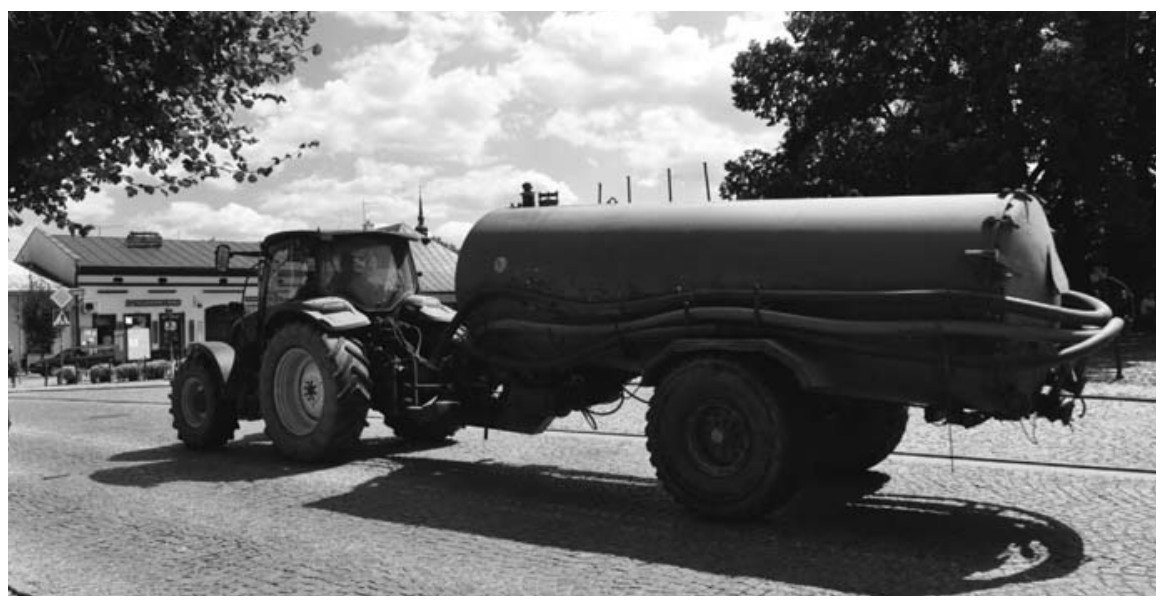

FIGURE 1. Wastewater from household holding tanks is transported to municipal wastewater treatment plants 
et al. 2009). Ecological engineering solutions e.g. constructed wetlands and sand filters, which are effective as on-site systems still are used marginally.

This study focuses on wastewater collected in holding tanks, which if managed properly, should be transported and treated in municipal wastewater treatment plant (Fig. 1). In Poland 90\% of population not connected to municipal WWTPs use holding tanks as a solution for wastewater management. The rest is served by on-site treatment systems, mostly septic systems with infiltration (Municipal infrastructure... 2014). The goal of the study is to estimate the scale of the abnormalities in wastewater management and related environmental hazard on the example of Poland. Uncontrolled sources of pollutants can be a hidden reason of difficulties with reaching good ecological status of rivers as well as unbalanced loads of pollutants discharges to Baltic Sea.

\section{MATERIAL AND METHODS}

Data for analysis were collected base on the questionnaire. The survey included information such as: (1) population; (2) water consumption; (3) number of people connected to the water supply system; (4) number of people connected to the sewerage network; (5) number of people using on-site wastewater treatment systems; (6) wastewater holding tanks; (7) volume of wastewater treated in municipal WWTPs; (8) volume of sewage transported by trucks from holding tanks and treated in municipal WWTP (9). Data collected in the survey were supple- mented by information from the Internet: e.g. type of the commune (rural/urbanrural), the area etc. To compare obtained results against the background of the whole country, official statistics were used (Environment 2014, Municipal infrastructure... 2014). The only criterion of selection of analyzed commune was total or partial lack of sewerage system. The analysis comprised 20 communes located in 5 voivodeships, of which 16 was rural and 4 urban-rural. Publication does not disclose the names of communes. Also the population and the area data have been rounded. The analysis covers years 2011-2014.

Based on the collected data and calculations: (1) the amount of wastewater from holding tanks transported to WWTPs (as the percent of wastewater collected); (2) the load of pollutants discharged to the environment in an uncontrolled manner were estimated. For the calculation of the volume of wastewater produced by holding tanks owners, unit water use (typical for each commune) and four people living in one household as an average was used. Obtained volumes were compared with official data collected from communes (volume of wastewater delivered to the receiving stations of WWTPs). The difference shows the volumes of wastewater discharged to the environment in an uncontrolled manner. Estimation of pollutant loads was limited to two indicators (nitrogen and phosphorus), and calculated base on the unit loads given by German standard ATV-DVWK-A 131 E (Table 1), as it is used as a rule in Poland in the process of designing of wastewater infrastructure. 
TABLE 1. Unit loads of pollutants in raw wastewater $\left[\mathrm{g} \cdot\right.$ person $^{-1} \cdot \mathrm{day}^{-1}$ ]

\begin{tabular}{|l|c|c|c|}
\hline Index & $\begin{array}{c}\text { Rural areas } \\
\text { Polish research } \\
\text { (Biedugnis 2006) }\end{array}$ & $\begin{array}{c}\text { Municipal } \\
\text { German standard } \\
\text { (ATV-DVWK-A 131 E) }\end{array}$ & $\begin{array}{c}\text { Municipal } \\
\text { Polish research } \\
\text { (Heidrich and Kozak 2009) }\end{array}$ \\
\hline Solids & $65-90$ & 70 & 66 \\
\hline$B O D_{5}$ & $45-85$ & 60 & 68 \\
\hline$C O D$ & - & 120 & 125 \\
\hline$N_{\text {tot }}$ & $10-18$ & 11 & 12.8 \\
\hline$P_{\text {tot }}$ & $2-7^{*}$ & 1.8 & 1.96 \\
\hline
\end{tabular}

From the time of this publication unit load of $\mathrm{P}$ decreased significantly as the result of progressive changes in the composition of detergents used in households. According to Pistelok (2010), the unit P load for Polish conditions amounts $1.9 \mathrm{~g} \cdot \mathrm{person}^{-1} \cdot \mathrm{day}^{-1}$.

\section{RESULTS}

There are in total 2,174 communes in Poland. Analyzed group of 20 communes is described in details in Table 2. They differ both in terms of population, area and location, as well as the infrastructure: amount of population served by the water supply system and sewerage network.

Population connected to water supply system varied in different communes from 35.2 to $97.3 \%$ (with the average at $77.4 \%$ ), which is less than the Polish average $(88 \%)$. The unit water use varied from 19 to $55.3 \mathrm{~m}^{3} \cdot$ person $^{-1} \cdot$ year $^{-1}$ (mean 36.3) and is higher than the country average. Unit water use in Poland in cities amounts to $\left(34 \mathrm{~m}^{3} \cdot\right.$ person $^{-1} \cdot$ year $^{-1}$ and in rural areas to $26.3 \mathrm{~m}^{3} \cdot$ person $^{-1} \cdot$ year $^{-1}$ (Municipal infrastructure... 2014). In one of analyzed communes only $6.6 \%$ residents were connected to sewer system, by contrast, in another $97.8 \%$. The average $(40.5 \%)$ was lower than for the country $(65.1 \%)$. The population using wastewater holding tanks in analyzed group of communes varied over a wide range from 1.7 to $93.2 \%$.

In 9 out of 20 analyzed communes, the amount of sewage transported and discharged to the WWTPs was less than $10 \%$ of wastewater produced, including 5 communes below $5 \%$ (Table 2, Fig. 2). In the leading commune nearly $86 \%$ of wastewater from holding tanks was discharged to the receiving station of WWTP. On average, for the analyzed group of communes, $27 \%$ of stored wastewater ended in WWTPs. It means that on average, more than $70 \%$ of raw wastewater somehow were dispersed in the environment. Even more frightening picture can be obtained by analyzing official statistics (Environment 2014, Municipal infrastructure... 2014). Annual production of wastewater in Polish households amounts to $912.6 \mathrm{hm}^{3} \cdot \mathrm{year}^{-1}$. Considering $65.1 \%$ of wastewater served by sewerage systems and WWTPs there is still $318.5 \mathrm{hm}^{3} \cdot$ year $^{-1}$ of wastewater out of municipal treatment systems. Share of $90 \%$ of those households are served by wastewater holding tanks, what gives about $298.1 \cdot \mathrm{hm}^{3} \cdot$ year $^{-1}$ of wastewater, which should be transported to WWTP receiving stations. According to data of Central Statistical Office (Municipal infrastructure... 2014) from individual households only $15.6 \mathrm{hm}^{3}$ of wastewater was collected during the year, what gives the number of $5.2 \%$. That means 


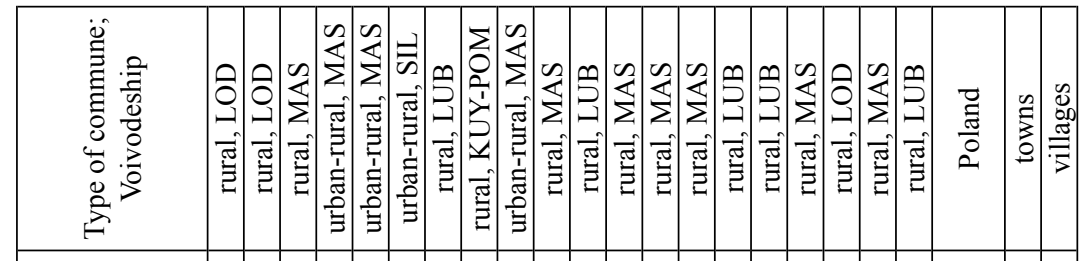

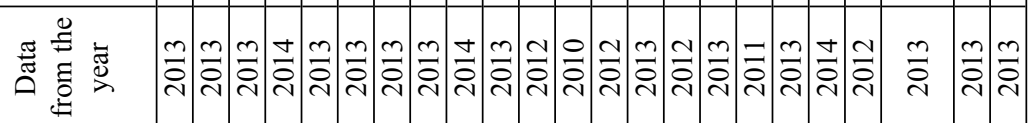

离

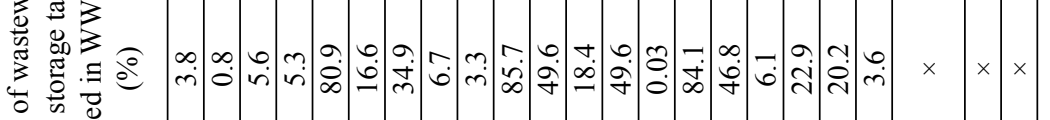

壱芯导

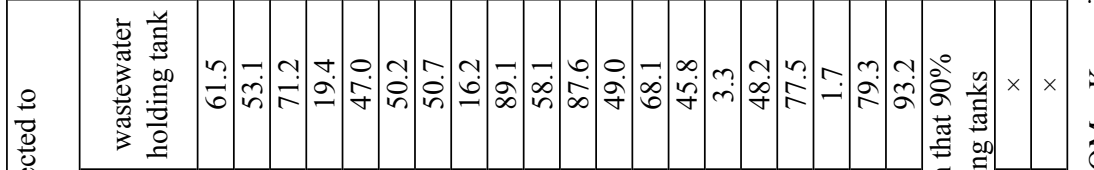

总

壳

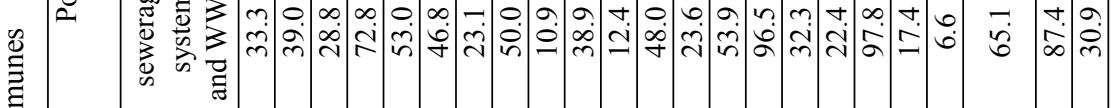

응

ర్ల

包

3

?

$\stackrel{0}{=}$

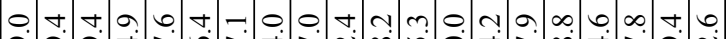

aे $+m$

.

. 호

可

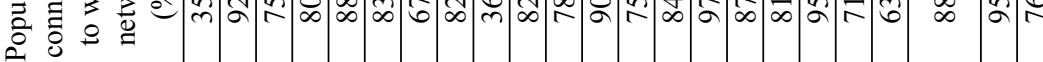

in

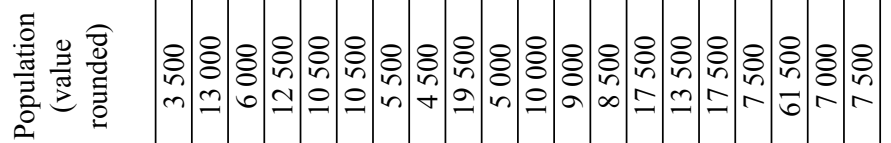

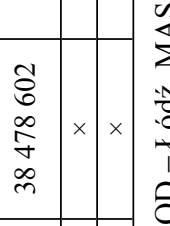

छृ

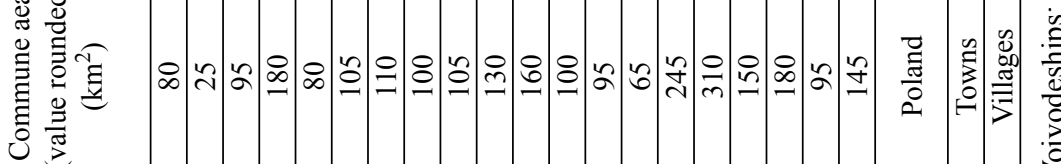

N

닐 


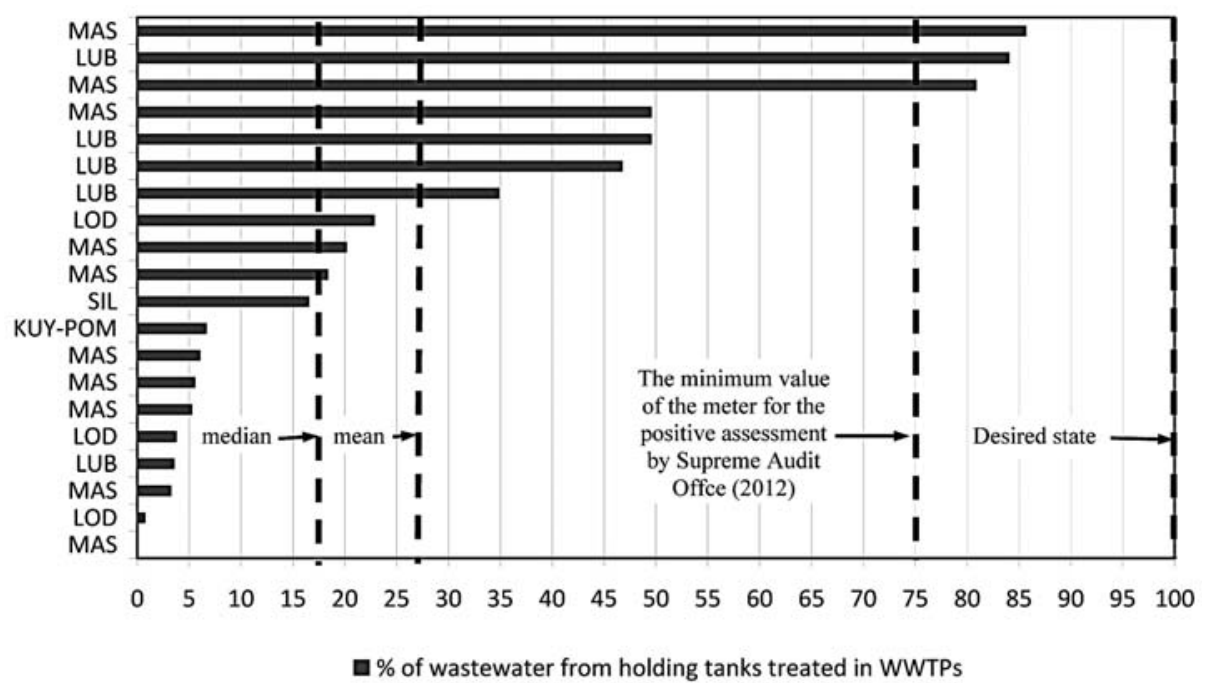

FIGURE 2. Precentege of liquid waste from holding tanks reaching receiving stations of WWTPs on example of analysed communes. Mean and median values are marked

that $282.6 \mathrm{hm}^{3} \cdot$ year $^{-1}$ of wastewater is dispersed in environment through the holding tanks leaking or pumping out on the fields. Due to failure of holding tank management, waste water treatment plants are hydraulically under-loaded causing problems in their operation $(\mathrm{Bu}-$ gajski and Satora 2009).

\section{DISCUSSION}

About 2,257,000 wastewater holding tanks were registered in Poland in 2013 (Municipal infrastructure... 2014), what gives population of about $9,000,000$ served by this type of wastewater management. The group of communes analyzed in the study is small comparing total number of communes in Poland (about 1\%), however comparing to other studies (Szustakowski and Halicki 2004, Municipal wastewater... 2012), author dares to say that obtained results more reflect Polish realities than official statistical data. Calculations show, that wastewater holding tanks can be a dispersed source of more $4,000 \mathrm{Mg}$ of phosphorus and $26,000 \mathrm{Mg}$ of nitrogen in the environment. To point out significance of those numbers, the total load of $\mathrm{P}$ and $\mathrm{N}$ to the Baltic Sea from the area of Poland estimated on 19,768 and $404,522 \mathrm{Mg} \cdot$ year $^{-1}$, respectively (HELCOM 2015). It gives significant share of $20 \%$ for $\mathrm{P}$ and $6 \%$ for $\mathrm{N}$ which is out of control. For comparison with actual outcomes, dispersed residential buildings in Gliwice district in Poland generates $15 \%$ of the load of phosphorus and $12.5 \%$ of nitrogen to the watershed (Dudek et al. 2014).

Analyzed communes discharged into the environment in an uncontrolled way from 0.05 to $11.4 \mathrm{Mg}$ of $\mathrm{P}$ and from 0.29 to $69.8 \mathrm{Mg}$ of $\mathrm{N}$ during the year. Per unit area it gives annual loss per ha of up to $0.2 \mathrm{~kg}$ of $P$ and $1.25 \mathrm{~kg}$ of N. Such loss of P is high, e.g. if com- 
pare with $\mathrm{P}$ export from arable land of $0.08-0.28 \mathrm{~kg} \cdot \mathrm{ha}^{-1} \cdot$ year $^{-1}$ of P (Verheyen et al. 2015). The majority of $P$ leaching from leaky holding tanks will be adsorbed and precipitated in the soil, depending upon soil composition, groundwater velocity and loading history. Due to the passage of time natural sorption capacity of soil will be saturated and exposure on the outflow $\mathrm{P}$ to groundwater will increase (Harman et al. 1996). Szustakowski and Halicki (2004) stated the outflow of sewage from leaking holding tanks resulted in associated increased phosphorus concentration in the Quaternary groundwater. Phosphorus contained in sewage spilled from holding tanks is a potential source of contamination of surface water due to run-off. For example for agricultural areas, the loss P by surface run-off is 30 times greater than that due to leaching and infiltration (Frissel 1997). A relatively small percentage of $\mathrm{P}$ may, however, also contaminate groundwater, especially in the areas where groundwater form the baseflow of rivers. For example in Ireland annual average contributions ranges from 30 to $80 \%$, with the maximum at the areas where aquifers are in good hydraulic connection to the river (Gill et al. 2009). According to German data, phosphorus content in groundwater can vary in the range of $0.03-0.11 \mathrm{mg} \cdot \mathrm{dm}^{-3}$ (Pistelok 2010). Raczuk et al. (2009) estimated phosphate concentrations in Polish wells on $0.2-4.9 \mathrm{mg} \cdot \mathrm{dm}^{-3}$ for shallow wells and $0.1-0.57 \mathrm{mg} \cdot \mathrm{dm}^{-3}$ for deep wells. Despite the fact that more and more people use the water supply systems ( $88 \%$ of population in Poland), high $\mathrm{P}$ concentration in groundwater may limit its usefulness for other purposes, e.g. for filling backyard ponds (Karczmarczyk et al. 2015). The sewage pumped out from holding tanks e.g. to roadside ditches contaminate the surface water directly. Generally it is believed that surface water is the last stage of $P$ life cycle, but preliminary studies (Patent application 2013) indicate that it can be recovered from the water and reused. In the case of nitrogen, as it is vulnerable to leaching, we will have to deal mostly with groundwater contamination. Elevated nitrate concentrations in groundwater are an indicator of wastewater or agricultural pollution. Nitrates also indicate potential microbial risk if the groundwater is used as a drinking water supply (Gill et al. 2009).

Any attempts to determine the statistical relationship between the amount of wastewater from holding tanks transported to the WWTPs and parameters of the commune (area, population, the amount of water consumed, level of development of water and sewerage infrastructure, number of holding tanks etc.) have not been successful. This suggests that we are dealing with the problem of people's mentality and the lack of appropriate control mechanisms of wastewater handling. The key question is what happens with wastewater from holding tanks if they don't reach municipal WWTPs. There are four possibilities: (1) the holding tank is leaking; (2) the owner empties it and spills the wastewater on soil or pumps it to the ditch (Fig. 3); (3) liquid waste haulers are unfair and instead bringing sewage to the receiving station of WWTP spilling them into a ditch or in a nearby forest; (4) unfair haulers deliver the liquid waste to receiving stations and/ 

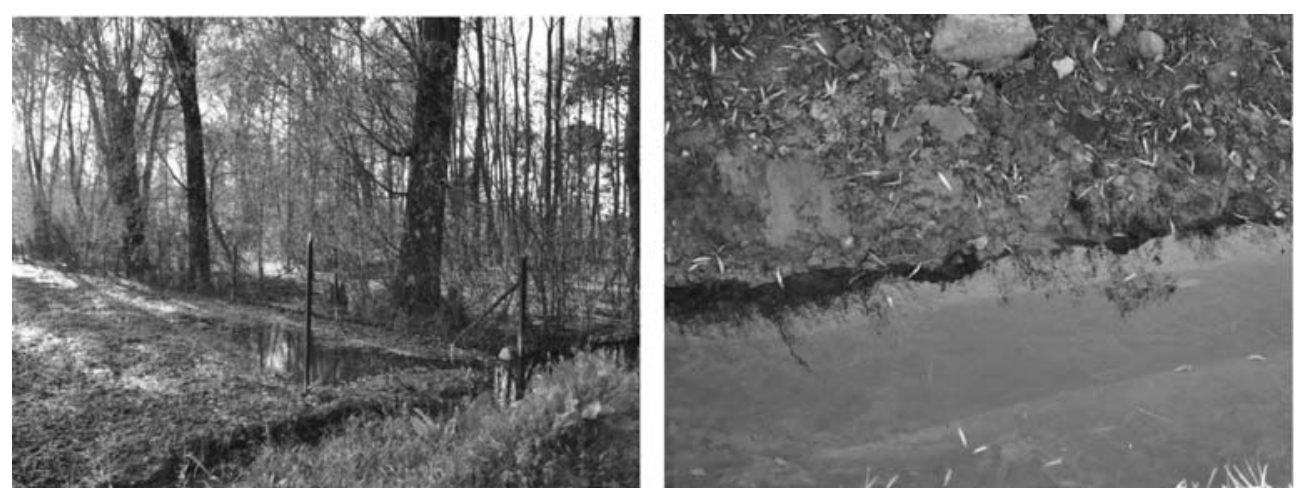

FIGURE 3. Wastewater from holding tank pumped out by the owner on the soil reaches the surface water (ditch)

/or hidden sewerage manholes, but without any legal confirmation (Błażejewski and Nawrot 2009). All these illegal activities could be restricted if municipalities fulfill their statutory duty of supervision. The control and keeping the records of the frequency of emptying holding tanks is one of the municipality duties, as well as the control of the liquid waste haulers (Water Law Act 2001). The cost of transport of sewage in Poland ranges from 3.4 to $10.3 \mathrm{EUR} \cdot \mathrm{m}^{-3}$. In some areas it is significant burden on the household budget. The lack of control offers the chance to avoid these costs. For comparison, the fee for sewage discharge to sewer stands at $0.3-8.3 \mathrm{EUR} \cdot \mathrm{m}^{-3}$. This fee cannot be avoided.

Results obtained in presented study are similar to those performed 10 years ago by Szustakowski and Halicki (2004). They estimated the outflow of sewage from leaking holding tanks at $80 \%$. That means, that although much has been done in the development of sewerage networks and municipal WWTPs, the inspection and education with regard to individual sewerage systems is still insufficient. Paradoxically, successful education in this field is becoming more and more difficult because contaminated wells already do not bother anyone as the water pipes are common. Low environmental awareness in this regard and the incompetence of the authorities, often driven by the convenience of officials and even fear for their own status. The majority of audits in municipalities is done on the basis of neighbors' denunciations but permanent control mechanism basically doesn't function.

Unequal development of water supply and sewerage network in Poland can be identified as a potential reason of described problem. The total length of water supply network in 2013 amounted 287.7 thousand $\mathrm{km}$ and the length of sewerage system only 132.9 thousand $\mathrm{km}$ (Municipal infrastructure... 2014). Although the even development of these networks was recorded as a duty in the Water Law Act (2001), its performance is often impossible for economic reasons. Most of the investments in the area of water and wastewater management in Poland are not implemented at the same time, but in the order, which leads to ridiculous situations, e.g.: multiple de- 
stroying and repairing the road surface, first as a result of pursuing water supply pipes, after that the sewage system in the coming years.

In this analysis, environmental impact of on-site wastewater treatment systems was not taken into account. In 2013 there were in total 155,000 of on-site wastewater systems in Poland (Municipal infrastructure... 2014), of which the vast majority are septic tanks with the drainfield (STS). They also can create real risk to the environment (Hartman et al. 1996, Szustakowski and Halicki 2004, Gill et al. 2009, Withers et al. 2014). According to a study of Jucherski and Walczowski (2001) wastewater discharged from STS to the soil have quality in the range of $331-558 \mathrm{mg} \cdot \mathrm{dm}^{-3}$ for $B O D_{5}, 88-164 \mathrm{mg} \cdot \mathrm{dm}^{-3}$ for total nitrogen and $14-50 \mathrm{mg} \cdot \mathrm{dm}^{-3}$ for $\mathrm{P}_{-} \mathrm{PO}_{4}$. The value of $152 \mathrm{mg} \cdot \mathrm{dm}^{-3}$ for total nitrogen has been also reported by Hartman et al. (1996). Comparing to the quality of the raw wastewater, treatment efficiency is inadequate. Moreover, in STS wastewater is distributed under the surface of the soil, making the control of the quality of discharged wastewater impossible. Following the recommendations of HELCOM (2007) maximum daily load per capita for wastewater treated in on-site systems should not exceed $8 \mathrm{~g} \cdot$ person $^{-1}$. - day ${ }^{-1}$ for $B O D_{5}, 0.65$ for total phosphorus and 10 for total nitrogen. It reflects the reduction of 80,70 and $29 \%$, respectively. Wastewater discharges from decentralized system (STS) may reach $0.05 \mathrm{Gg} \cdot \mathrm{year}^{-1}$ of P (Ott and Rechberger 2012). They may have more eutrophication impact than previously thought, requiring action at the household level (Withers et al. 2014). Legacy
$\mathrm{P}$ in soils, sediments and groundwater is an endemic and long-term source of $P$ inputs to surface waters via runoff, and is delaying the restoration of good ecological quality in many surface waters (Sharpley et al. 2013).

\section{CONCLUSIONS}

Under the EU Waste Framework Directive (Directive 2008/98/EC) domestic wastewater involving holding tanks or individual wastewater treatment must be recovered or disposed of without endangering human health or the environment. The reality deviates significantly from the objectives. No leakage control and lack of tank-emptying monitoring, unfair and fraudulent people behavior, submitting financial benefits over the state of the environment and the lack of environmental awareness - this is a picture reveals from the content of this publication. Negative ecological effect of improper management of wastewater holding tanks in Poland is increased by on-site wastewater treatment in rural areas, where $\mathrm{N}$ and $\mathrm{P}$ discharges are not limited in proper regulations. First step for the improvement has been made at the beginning of 2015, thanks to new legislation (Regulation... 2014), which requires treatment of domestic sewage in on-site plants to the standards for the agglomeration (depending on PE). Unfortunately, rural areas are not the part of this legislation.

Holding tanks are the dispersed sources of pollution and cannot be ignored in catchment management programs. Regulation of individual sewage management should be a priority in Phosphorus 
Reduction Programs being established on a base of the National Water Environment Programme (2010). Poland is the example but not only country in UE with holding tanks or STS as a dominating solution for on-site wastewater management. The result of analysis presented in this paper shows that there are still large gaps in the scale of wastewater management. This requires absolute compliance with the rules and the introduction of efficient control mechanism. Without resolute actions the EU objectives on achieving good ecological status of rivers and the protection of the Baltic Sea against eutrophication will not be achieved. The future of holding tanks in Poland depends on the education of the tank owners and the authorities of municipalities and their attention to compliance with the obligations of control stated in the Water Law Act (2001).

\section{Acknowledgments}

Even if in theory access to environmental data in Poland is free and available for public, in reality it requires patience and determination to find the helpful and responsible person, able to answer all required questions. I would like to thank my students from the course of "On-site wastewater treatment" in academic year 2014/2015 for their commitment to collection of the data used in this article. The course is given as a specialisation course for the third-year students of environmental engineering at the Faculty of Civil and Environmental Engineering of Warsaw University of Life Sciences - SGGW.

\section{REFERENCES}

Act on maintaining cleanliness and order in municipalities from 13 September 1996. Dz.U. 1996/132/622 (in Polish).

ATV-DVWK-A 131 E. Dimensioning of Single-Stage Activated Sludge Plants. German ATV-DVWK rules and standards. May 2000. URL: http://pl.scribd.com/ doc/53548101/atv-dvwk-a-131-e\#scribd.

ARNSCHEIDT J., JORDAN P., LI S., McCORMICK S., McFAUL R., McGROGAN H.J., NEAL M., SIMS J.T. 2007: Defining the sources of low-flow phosphorus transfers in complex catchments. Sci. Total Environment 382, 1-13.

BŁAŻEJEWSKI R., NAWROT T. 2009: Jak uszczelnić system gromadzenia i dowożenia nieczystości ciekłych? $G a z$, Woda i Technika Sanitarna 9, 2-3.

BIEDUGNIS S., SMOLARKIEWICZ M., ZIELIŃSKI S., BYCZOT T. 2006: Premises for computer aided calculation of household sewage treatment plants. Rocznik Ochrona Srodowiska 8, 113-132. (Engl. Summ.)

BUGAJSKI P., SATORA S. 2009: The balance of sewage inflowing and brought to the treatment plant based on example of the chosen object. Infrastructure and Ecology of Rural Areas 5, 73-82.

Directive 2008/98/EC of the European Parliament and of the Council of 19 November 2008 on waste and repealing certain Directives (Waste Framework Directive).

DUDEK R., GÓRA M., GRABARSKA G., IWANIAK M., JAROSIŃSKI W., KOSTECKI M., KOWALSKI E., KURCZYŃSKI K. et al. 2014: Developement of phosphorus reduction program. Regional Water Management Board in Gliwice, Gliwice (in Polish).

Environment, 2014. Statistical Informations and Elaborations. Central Statistical Office, Warsaw (in Polish). 
EVEBORN D., GUSTAFSSON J.P., ELMEFORS E, YU L., ERIKSSON A-C., LJUNG E., RENMAN G. 2014: Phosphorus in soil treatment systems: 4 accumulation and mobility. Water Research 64, 42-52.

FRISSEL M.J. 1997: Cycling of mineral nutrients in agricultural ecosystems. Agroecosystems $4,1-354$.

GILL L.W., O'LUANAIGH N., JOHNSTON P.M., MISSTEAR B.D.R., O'SUILLEABHAIN C. 2009: Nutrient loading on subsoils from on-site wastewater effluent, comparing septic tank and secondary treatment systems. Water Research 43, 2739-2749.

HARTMAN J., ROBERTSON W.D., CHERRY J.A., ZANINI L. 1996: Impacts on a Sand Aquifer from an Old Septic System: Nitrate and Phosphate. Ground Water 34 (6), 1105-1114.

HEIDRICH Z., KOZAK T. 2009: Unit loads of pollutants characterizing municipal wastewater. Gaz, Woda i Technika Sanitarna 12, 20-22 (in Polish).

HELCOM recommendation 28E/6 adopted 15 November 2007. On-site wastewater treatment of single family homes, small businesses and settlements up to 300 person equivalents (P.E.).

HELCOM 2015. Updated Fifth Baltic Sea pollution load compilation (PLC-5.5). Baltic Sea Environment Proceedings 145.

JUCHERSKI A., WALCZOWSKI A. 2001: Infiltration systems. Treatment or discharge of untreated wastewater to the soil? Wiadomości Melioracyjne i Łakarskie 3, 131-132 (in Polish).

KARCZMARCZYK A., SKOWRON S., MOSIEJ J., BARYŁA A. 2009: The needs and possibilities of constructing on site wastewater treatment plants in forester's lodges. Journal of Water and Land Development 13a, 273-282.

KARCZMARCZYK A., BUS A., BARYŁA A. 2015: The use of reactive materials in rainwater management in urban residentials. Infrastructure and Ecology of Rural Areas 4 (1), 1089-1096. doi: http://dx.medra.org/10.14597/infraeco. 2015.4.1.087 (Engl. summ.).

Municipal infrastructure in the year 2013, 2014. Statistical Informations and Elaborations. Central Statistical Office (in Polish).

National Programme of Municipal Wastewater Treatment, 2003. Ministry of Environment (in Polish).

National Water-Environment Programme, 2010. National Council of Water Management (in Polish).

OTT Ch., RECHBERGER H. 2012: The European phosphorus balance. Resour-ces, Conservation and Recycling 60, 159-172.

Patent application PL P403571, 2013: Filter for removal of pollutants, especially from small water bodies by A. Karczmarczyk and A. Bus.

PISTELOK F. 2010: Methodology for the development of phosphorus reduction program. LEMTECH Konsulting Sp. z o.o., Kraków (in Polish).

RACZUK J., BIARDZKA E., MICHALCZYK M. 2009: Nitrogen in water from wells in the scope of health risk of Wodynie commune population. Water - Environment - Rural Areas 9/1 (25), 87-97 (Engl. summ.).

Regulation of the Minister of Environment on conditions that must be met for the discharge of sewage into water or soil and on substances particularly harmful to the aquatic environment. Dz.U. 2014/0/1800 (in Polish).

SHARPLEY A., JARVIE H.P., BUDA A., MAY L., SPEARS B., KLEINMAN P. 2013: Phosphorus legacy: Overcoming the effects of past management practices to mitigate future water quality impairment. Journal of Environmental Quality 42, 1308-1326.

SUMISŁAWSKI W. 2013: National Programme of Wastewater Treatment - whether its fulfillment is real? Presentation of the President of the National Council of Water Management at the International Congress of Environmental Protection ENVICON, 7-8 Oct. (in Polish). 
Municipal wastewater management on the areas out of municipal sewer system in years 2009-2011, 2012. Supreme Audit Office. URL: https://www.nik.gov.pl/ plik/id,3794,vp,4835.pdf (in Polish).

SZUSTAKOWSKI M., HALISKI W. 2004: Assessment of infiltration of phosphorus into the groundwaters in the soil loaded with wastewater. Gospodarka Wodna 4, 39-142 (in Polish).

VERHEYEN D., VAN GAELEN N., RONCHI B., BATELAAN O., STRUYF E., GOVERS G., MERCKX R., DIELS J. 2015: Dissolved phosphorus transport from soil to surface water on catchments with different land use. Ambio 44 (Suppl. 2), 228-240.

Water Law Act from 18 July 2001. Dz.U. 2001/115/1229 (in Polish).

WILLIAMS R., KELLER V., VOß A., BÄRLUND I., MALVE O., RIIHIMÄKI J., TATTARI S., ALCAMO J. 2012: Assessment of current water pollution loads in Europe: estimation of gridded loads for use in global water quality models. $\mathrm{Hy}$ drol. Process. 26, 2395-2410.

WITHERS P.J.A., JORDAN P., MAY L., JARVIE H.P., DEAL N.E. 2014: Do septic tank systems pose a hidden threat to water quality? Frontiers in Ecology and the Environment 12 (2), 123-130.

WOOD A., BLACKHURST M., HAWKINS T., XUE X., ASHBOLT N., GARLAND J. 2015: Cost-effectiveness of nitrogen mitigation by alternative household wastewater management technologies. Journal of Environmental Management 150, 344-354.
Streszczenie: Zbiorniki bezodpływowe jako potencjalne źródło zanieczyszczeń wód i ziemi w Polsce. Niewłaściwie eksploatowane zbiorniki bezodpływowe są często niedoszacowanym źródłem zanieczyszczeń odprowadzanych do ziemi, wód gruntowych i powierzchniowych. Co do zasady nieczystości ciekłe gromadzone w zbiornikach bezodpływowych powinny być transportowane i oczyszczane w oczyszczalni ścieków. W Polsce użytkowanych jest 2257000 zbiorników bezodpływowych, głównie na obszarach niezurbanizowanych. W artykule przedstawiono wyniki analizy zagospodarowania nieczystości ciekłych w 20 gminach wiejskich i miejsko-wiejskich, które zostały losowo wybrane spośród ogólnej liczby 2174 gmin w Polsce. Jedynym kryterium, które musiała spełniać gmina, był częściowy lub całkowity brak sieci kanalizacyjnej. Analiza zgromadzonych danych wykazała, że średnio tylko $27 \%$ nieczystości ciekłych ze zbiorników bezodpływowych trafia do punktów zlewnych oczyszczalni ścieków. Wartość przeciętna (mediana) jest jeszcze mniejsza i wyniosła 17,5\%. W efekcie nieprawidłowej gospodarki nieczystościami ciekłymi, ponad $4000 \mathrm{Mg}$ fosforu i 26000 $\mathrm{Mg}$ azotu rozprasza się w środowisku naturalnym w sposób niekontrolowany. To niekontrolowane źródło zanieczyszczeń może być jednym z powodów istnienia utrudnień w osiągnięciu dobrego stanu ekologicznego rzek i co w konsekwencji może wpływać na jakość wód Morza Bałtyckiego.

\section{MS. received April 2016}

\section{Author's address:}

Agnieszka Karczmarczyk

Katedra Kształtowania Środowiska

Wydział Budownictwa i Inżynierii Środowiska SGGW

ul. Nowoursynowska 159

02-776 Warszawa, Poland

e-mail: agnieszka_karczmarczyk@sggw.pl 